\title{
EVALUASI PERUBAHAN LINGKUNGAN WILAYAH PESISIR SURABAYA TIMUR SIDOARJO DENGAN MENGGUNAKAN CITRA SATELIT MULTITEMPORAL
}

\author{
Grace Idolayanti Moko', Wiweka², \\ (Diterima tanggal : 14 Agustus 2011; Disetujui tanggal : 14 Desember 2011)
}

\begin{abstract}
ABSTRAK
Wilayah pesisir merupakan daerah pertemuan antara darat dan laut; ke arah darat meliputi bagian daratan, baik kering maupun terendam air, yang masih dipengaruhi sifat - sifat laut seperti pasang surut, angin laut, dan perembesan air asin; sedangkan ke arah laut wilayah pesisir mencakup bagian laut yang masih dipengaruhi oleh proses - proses alami yang terjadi di darat seperti sedimentasi dan aliran air tawar, maupun yang disebabkan oleh kegiatan manusia di darat seperti penggundulan hutan dan pencemaran. Surabaya Timur - Sidoarjo merupakan daerah yang relatif mengalami perubahan. Di kawasan pesisir ini juga mengalami peristiwa penting yaitu peristiwa lumpur Lapindo. Terdapat beberapa metode yang dapat digunakan untuk memantau perubahan pada wilayah pesisir. Salah satunya menggunakan teknologi penginderaan jauh. Hal ini dilakukan karena data penginderaan jauh memilki wilayah cakupan yang luas, cepat, serta efisien. Data yang digunakan adalah citra satelit ALOS/AVNIR-2 tahun 2006 dan 2008 serta SPOT-4 tahun 2009. Data tersebut digunakan untuk menganalisis perubahan tutupan lahan, garis pantai, serta tingkat kekeruhan air laut. Metode klasifikasi terbimbing digunakan untuk mengetahui tutupan lahan di wilayah pesisir Surabaya Timur - Sidoarjo, sedangkan kekeruhan air laut menggunakan algoritma Total Suspended Solid (TSS). Berdasarkan hasil penelitian, didapatkan perubahan tutupan lahan yang signifikan pada kelas pemukiman, rumput/tanah kosong, dan empang. Dimana sejak tahun 2006 hingga 2009, luasan pemukiman selalu bertambah yaitu 184,7 ha , sedangkan empang dan rumput/tanah kosong mengalami penurunan luasan yaitu kelas empang sebesar 48,04 ha dan rumput/tanah kosong sebesar 199,31 ha. Untuk tingkat kekeruhan air laut, nilai yang mendominasi wilayah perairan Surabaya - Sidoarjo adalah 0-200mg/l. Sejak tahun 2006 hingga 2009 terjadi perubahan garis pantai yang diikuti dengan terjadinya perubahan daratan. Pada tahun $2006-2008$ perubahan daratan sebesar 51,01 ha sedangkan tahun 2008 - 2009 perubahannya sebesar 18,92 ha.
\end{abstract}

Kata kunci : Pesisir, Tutupan Lahan, Garis Pantai, Kekeruhan Air Laut, SPOT-4, ALOS/AVNIR-2

\begin{abstract}
Coastal region is an area of encounter between land and sea; landward coastal areas include parts of the mainland, either dry or submerged with water, which is still influenced by the characteristic of ocean such as tides, ocean breezes, and salinity intrusion, while on the seaward coastal areas includes part of the sea that is still influenced by natural process that occurs on land such as sedimentation and freshwater streams, as well as those caused by human activities on land such as deforestation and pollution. East Surabaya - Sidoarjo is a coastal area that is relatively unchanged. Also in this coastal region experienced many important events, one of this event called Lapindo mud. There are several methods that can be used to monitor changes in coastal territory. One of them using a multitemporal remote sensing technology. This is done because the remote sensing data has an extensive coverage area, quickly and efficient. The data used is ALOS/AVNIR-2 satellite imagery in 2006 and 2008 and SPOT-4 in 2009. The data is used to analyze changes in land cover, shoreline, and the level of sea water turbidity. Supervised classification methods is used to determine land cover in coastal areas of Surabaya-Sidoarjo, while the turbidity of seawater using an algorithm Total Suspended Solid (TSS).

Based on the results of the study, significant changes in land cover in the class settlement has been found, the grass / bare soil, and ponds. Where from 2006 to 2009, the residential area of 184.7 ha is always increasing, while the ponds and the grass / bare soil decreased the area of 48.04 ha of ponds class and grass / bare soil of 199.31 ha. For sea water turbidity levels, the class that dominated the territorial waters of Surabaya - Sidoarjo is $0-200 \mathrm{mg} / 1$. From 2006 to 2009 changes in the coastline which was followed by changes in the mainland. In the year $2006-2008$ The land change alteration is 51,01 ha while in 2008 to 2009 the alteration is 18.92 .
\end{abstract}

Keywords: Coastal Area, Land Cover, Shorelines, Sea Water Turbidity, SPOT-4, ALOS/AVNIR-2

${ }^{1}$ Teknik Geomatika-ITS, Surabaya, 60111, Indonesia

${ }^{2}$ Pusat Pemanfaatan Penginderaan Jauh LAPAN, J1. LAPAN 70 Pekayon-Pasar Rebo, Jakarta, Indonesia Email : wiweka@yahoo.com 


\section{PENDAHULUAN}

\section{Latar Belakang}

Surabaya dan Sidoarjo merupakan pusat kegiatan perindustrian di wilayah Indonesia bagian timur yang mengalami perkembangan yang cukup pesat, tidak terkecuali pesatnya pertumbuhan penduduk. Pertumbuhan penduduk yang pesat menye-babkan kebutuhan akan lahan menjadi semakin besar.

Salah satu peristiwa yang terjadi d pesisir SurabayaTimur - Sidoarjo yaitu peristiwa Lumpur Lapindo yang terjadi pada 29 Mei 2006 di Desa Renokenongo, Kabupaten Sidoarjo, Jawa Timur. Berdasarkan penelitian terdahulu yang dilakukan oleh Mayasari (2010) menggunakan citra satelit Landsat 7 ETM+ tahun 2003 dan 2006 serta SPOT-4 tahun 2009, didapatkan bahwa nilai Total Suspended Sediment (TSS) yang dominan untuk wilayah Surabaya - Sidoarjo adalah 25-125 mg/l.

Untuk mengetahui besarnya perubahan perubahan tersebut dapat digunakan teknologi penginderaan jauh yang berbasis citra satelit. Teknologi ini mampu memberikan informasi spasial dipermukaan bumi baik darat maupun laut secara signifikan.

\section{Perumusan Masalah}

Seberapa jauh citra satelit ALOS/AVNIR-2 dan SPOT-4 dapat digunakan untuk mengidentifikasi perubahan tutupan lahan, perubahan garis pantai, serta perubahan tingkat kekeruhan air laut wilayah pesisir dan perairan Surabaya Timur - Sidoarjo yang terjadi pada tahun 2006 sampai tahun 2009.

\section{Batasan Masalah}

Wilayah studi yang digunakan adalah wilayah pesisir dan perairan Surabaya Timur sampai pesisir Sidoarjo.

Data yang digunakan dalam penelitian ini adalah citra satelit ALOS/AVNIR-2 tahun 2006 dan 2008 serta SPOT-4 tahun 2009.

Hasil penelitian adalah analisis perubahan tutupan lahan, perubahan garis pantai, serta perubahan kekeruhan air laut di wilayah pesisir dan perairan Surabaya Timur dan Sidoarjo yang disajikan dalam bentuk peta.

\section{Tujuan dan Manfaat}

Tujuan dalam penelitian ini, yaitu menganalisis perubahan tutupan lahan, perubahan garis pantai, dan perubahan tingkat kekeruhan air laut wilayah pesisir dan perairan pesisir Surabaya Timur - Sidoarjo yang disebabkan oleh adanya peristiwa Lumpur Lapindo dengan menggunakan citra satelit multitemporal.

Manfaat yang dapat diambil yaitu memberikan informasi berupa peta tutupan lahan, perubahan garis pantai, serta informasi hasil identifikasi perubahan tingkat kekeruhan air laut wilayah pesisir dan perairan yang diharapkan dapat digunakan sebagai landasan dalam rencana tata ruang wilayah pesisir.

Informasi geospasial yang dihasilkan pada penelitian ini merupakan bagian dari target pemantauan, deteksi, identifikasi parameter fisis yang ada di daratan, lautan serta udara dalam rangka pembangunan database dan analisis spasial lingkungan Surabaya berbasiskan data penginderaan jauh. 


\section{METODOLOGI}

\section{Lokasi Penelitian}

Kegiatan Penelitian ini dilakukan dilakukan di sekitar pesisir Surabaya Timur - Sidoarjo. Daerah penelitian secara administratif termasuk dalam wilayah Kotamadya Surabaya dan Kabupaten Sidoarjo

\section{Data dan Peralatan}

Data yang digunakan dalam penelitian ini adalah :

Citra satelit ALOS/AVNIR-2 6-10-2006 dan 11-7-2008 serta SPOT-4 21-7-2009.

Citra satelit Landsat Ortho.

Peta RBI area Surabaya dan Sidoarjo.

Data pengukuran sampel air laut.

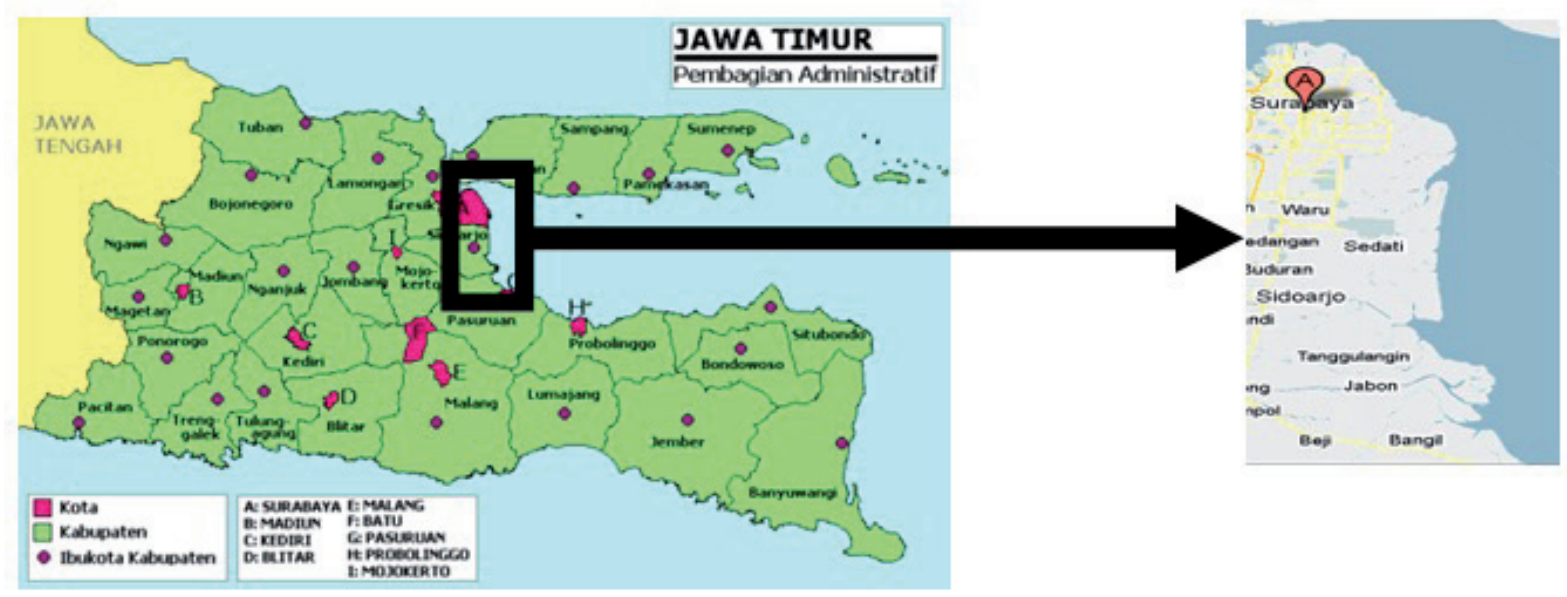

Gambar 1. Lokasi Penelitian

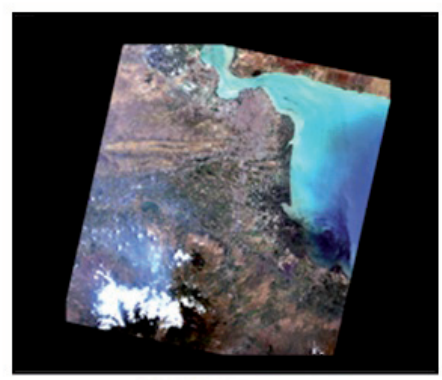

(a)

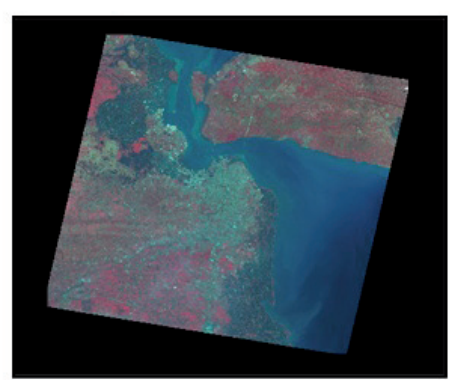

(c)

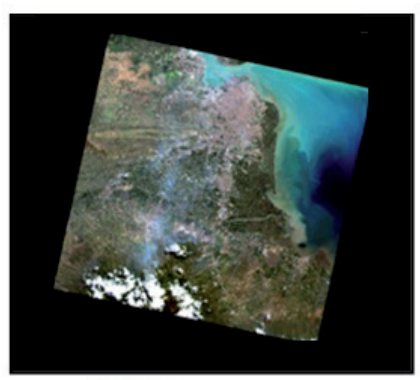

(b)

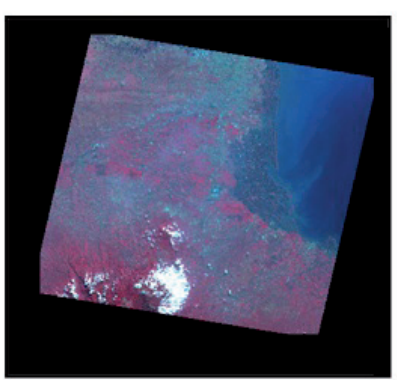

(d)
Gambar 2.

(a) Citra ALOS/AVNIR-2 tahun 2006 kombinasi band 321 ,

(b) Citra ALOS/AVNIR-2 tahun 2008 kombinasi band 321 ,

(c) Citra SPOT-4 path/row 297/364

tahun 2009 kombinasi band 123, (d) Citra SPOT-4 path/row 297/365 tahun 2009 kombinasi band 123 


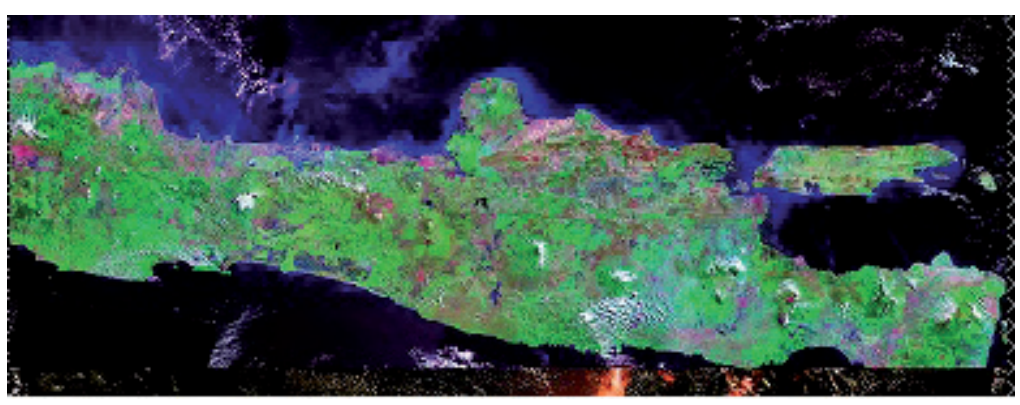

Gambar 3. Citra Landsat Ortho ETM-7+ Kombinasi Band 321

Sedangkan peralatan yang digunakan adalah: $\quad$ Water Quality Checker dan GPS navigasi

Perangkat Lunak (Software)

ER Mapper 7.0, Matlab, ArcGis 9.3

Peralatan Lapangan

\section{Pengolahan Data}

Adapun untuk diagram alir tahapan pengolahan data adalah sebagai berikut :

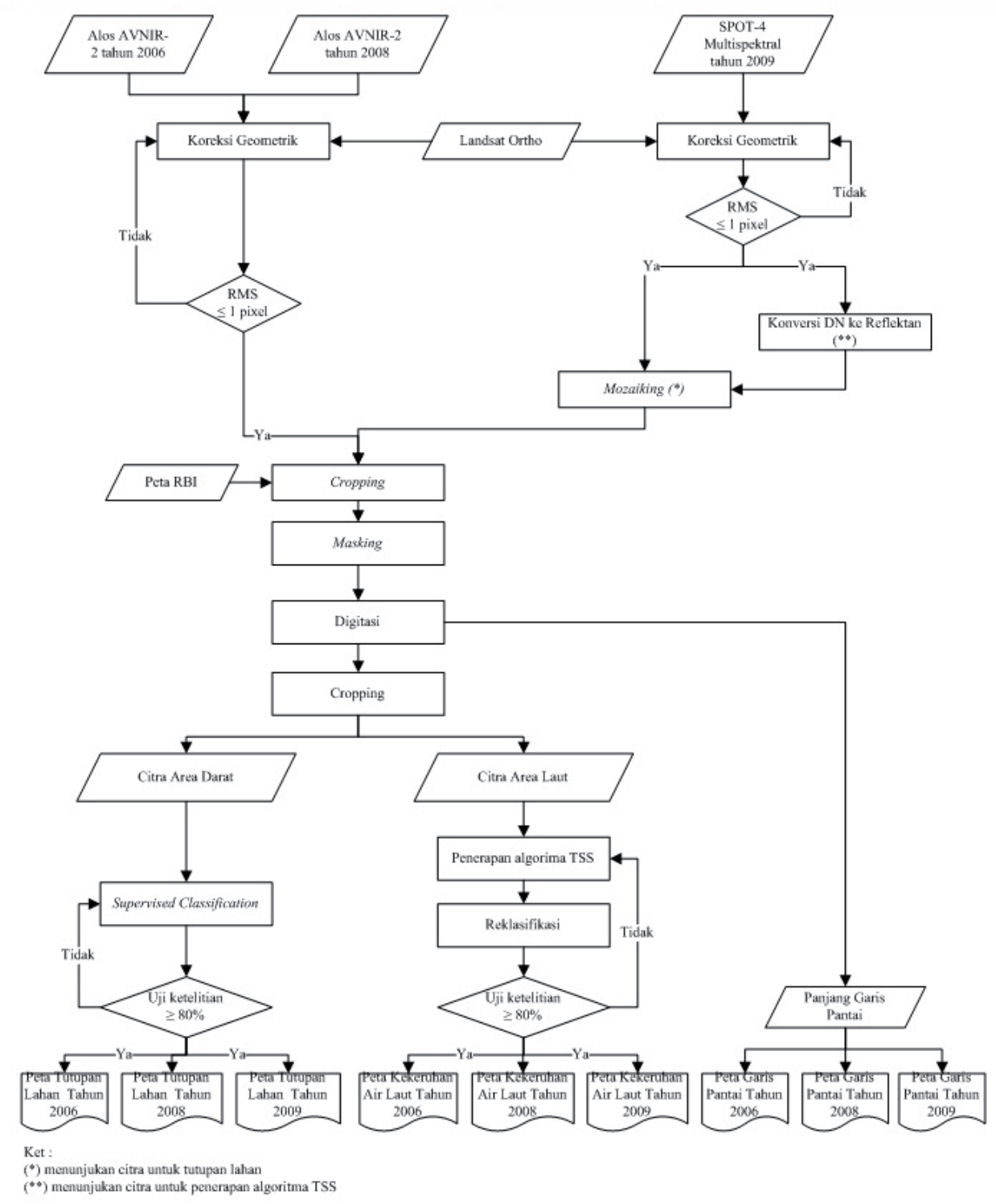

Gambar 4. Diagram Alir Pengolahan Data 


\section{HASIL DAN PEMBAHASAN}

\section{Koreksi Geometrik}

Desain jaring SoF untuk koreksi geomteri setiap citra pada Gambar 5.

Berikut ini tabel hasil koreksi geometrik dan perhitungan strengh of figure (Sof).

\section{Konversi DN ke Reflektan}

Konversi DN ke Reflektan dilakukan pada citra satelit SPOT-4 mengunakan input nilai reflektan. Persamaan yang digunakan :

Digital Number (DN) ke Spectral Radiance

$$
L_{\lambda}=D N /\left(G_{\lambda}{ }^{*} A_{\lambda}\right)+B_{\lambda} \ldots \ldots \ldots \ldots \ldots
$$

\section{Spectral Radiance ke Reflectance}

$\rho_{p}=\frac{\pi \times L_{\lambda} \times d}{E S U N_{\lambda} \times \cos \theta_{s}}$

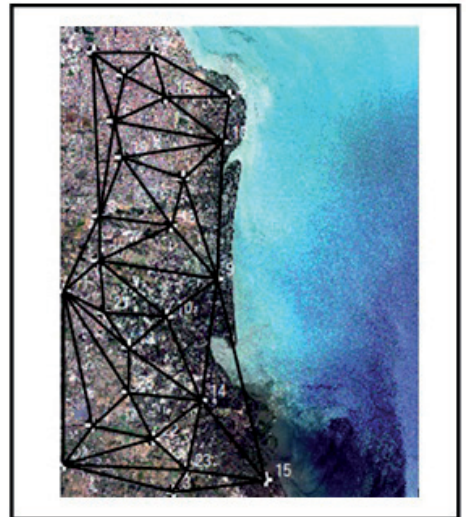

(a)

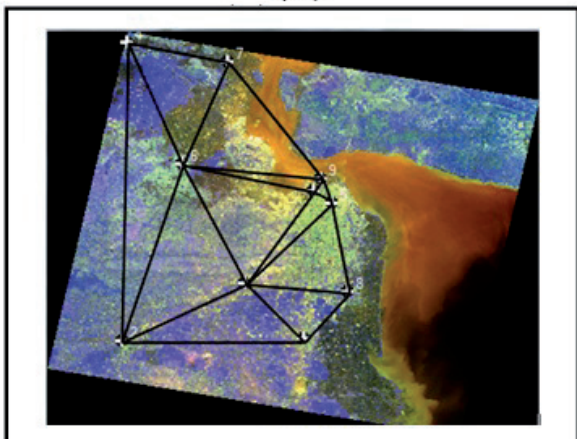

(c)
Tabel 1. Hasil Koreksi Geometrik Dan Perhitungan So

\begin{tabular}{|c|c|c|c|}
\hline Citra & $\begin{array}{c}\text { Total } \\
\text { RMSe }\end{array}$ & $\begin{array}{c}\text { Rata-rata } \\
\text { RMSe }\end{array}$ & Besar SoF \\
\hline $\begin{array}{c}\text { ALOS/AVNIR-2 tahun } \\
2006\end{array}$ & 8,578 & 0,343 & 0,000545 \\
\hline $\begin{array}{c}\text { ALOS/AVNIR-2 tahun } \\
\text { 2008 }\end{array}$ & 6,600 & 0,264 & 0,000798 \\
\hline $\begin{array}{c}\text { SPOT-4 Tahun 2009 } \\
\text { path/row 297/364 }\end{array}$ & 1,964 & 0,196 & 0,006250 \\
\hline $\begin{array}{c}\text { SPOT-4 Tahun 2009 } \\
\text { path/row 297/365 }\end{array}$ & 2,390 & 0,239 & 0,006250 \\
\hline
\end{tabular}

\section{Keterangan :}

$L=$ Spectral Radiance At Sensor Aperture (mWcm-2.ster-1. $\mu \mathrm{m}-1)$.

$D N=$ Digital Number

$\mathrm{G}_{\lambda}=$ Gain

$\mathrm{A}_{\lambda}=$ Absolute Correction

$\mathrm{B}_{\lambda}=$ Bias

$\rho=$ Unitless Planetary Reflectance At The Satellite (Dalam Skala 0-1)

$\pi \quad=3.141593$

$d^{2} \quad=\quad$ Earth Sun Distance In Astronomical Units.

$J D=$ Julian Day (Day Number In The Year Of Image Acquisition).

ESUN = Mean Solar Exoatmospheric Spectral Irradiance ( $m$ W.cm-2. $\mu m-1$ atau Wm-2.um-1).

$\Theta_{s} \quad=\quad$ Sun Zenith (degree) $=90^{\circ}$-Sun Elevation

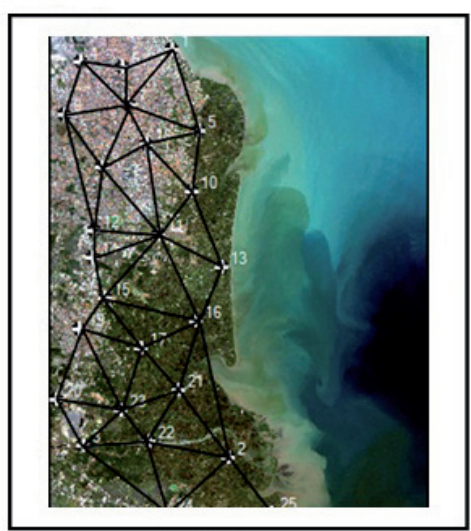

(b)

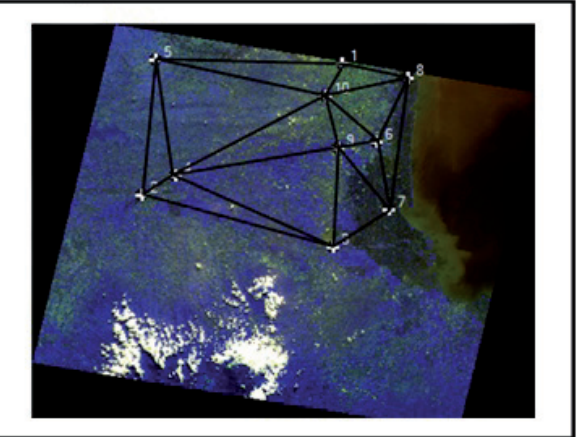

(d)

Gambar 5. Desain Jaring SoF :(a) ALOS/AVNIR Tahun 2006, (b) ALOS/AVNIR-2 Tahun 2008, (c) SPOT-4 Multispektral Tahun 2009 Path/Row 297/364, (d) SPOT-4 Tahun 2009 Path/Row 297/365 
Tabel 2. Hasil Konversi DN Ke Reflektan

\begin{tabular}{|c|c|c|c|c|}
\hline $\begin{array}{l}\text { Tanggal } \\
\text { Citra }\end{array}$ & Band & $\begin{array}{l}\text { Nilai } \\
\text { DN }\end{array}$ & Radians & $\begin{array}{c}\text { Nilai } \\
\text { Reflektan }\end{array}$ \\
\hline \multirow{4}{*}{$\begin{array}{c}\text { SP4_21- } \\
0 \overline{7}- \\
2009 \_297 / \\
3 \overline{6} 4\end{array}$} & 1 & $\begin{array}{l}12- \\
254\end{array}$ & $\begin{array}{l}9,73325634- \\
206,0205841\end{array}$ & $\begin{array}{c}0,022454- \\
0,475281\end{array}$ \\
\hline & 2 & $\begin{array}{l}47- \\
255\end{array}$ & $\begin{array}{c}21,26450157- \\
115,3712311 \\
\end{array}$ & $\begin{array}{l}0,05766- \\
0,312836\end{array}$ \\
\hline & 3 & $\begin{array}{l}75- \\
255\end{array}$ & $\begin{array}{c}42,54144287- \\
144,6408997\end{array}$ & $\begin{array}{l}0,171934- \\
0,584575\end{array}$ \\
\hline & 4 & $1-255$ & $\begin{array}{c}0.01354523096- \\
3,454033852\end{array}$ & $\begin{array}{c}0.000247- \\
0,063028\end{array}$ \\
\hline \multirow{4}{*}{$\begin{array}{c}\text { SP4_21- } \\
0 \overline{7}- \\
2009 \_297 / \\
365\end{array}$} & 1 & $\begin{array}{l}12- \\
254\end{array}$ & $\begin{array}{l}9,73325634- \\
206,8316956\end{array}$ & $\begin{array}{c}0,022529- \\
0,478733\end{array}$ \\
\hline & 2 & $\begin{array}{l}31- \\
255\end{array}$ & $\begin{array}{c}14,02552223- \\
115,3712311\end{array}$ & $\begin{array}{c}0,038157- \\
0,313872\end{array}$ \\
\hline & 3 & $\begin{array}{l}50- \\
255\end{array}$ & $\begin{array}{c}28,36096191- \\
144,6408997\end{array}$ & $\begin{array}{c}0,115002- \\
0,586512\end{array}$ \\
\hline & 4 & $1-255$ & $\begin{array}{c}0,01354523096- \\
3,454033852\end{array}$ & $\begin{array}{c}0,000248- \\
0,063237\end{array}$ \\
\hline
\end{tabular}

\section{Penggabungan Citra (Mosaiking)}

Penggabungan citra dilakukan pada citra satelit SPOT-4, karena area penelitian berada dalam 2 scene yang bertampalan. Sedangkan pada citra ALOS/AVNIR-2 tidak dilakukan penggabungan citra karena area penelitian berada pada 1 scene saja. Proses ini dilakukan pada citra yang sudah terkoreksi.

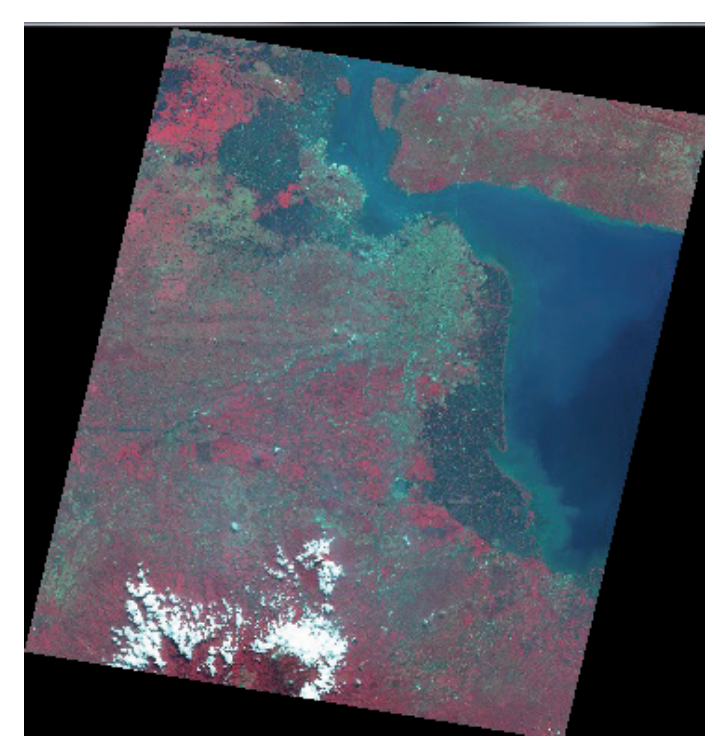

Gambar 6. Hasil Penggabungan Citra Pada SPOT-4 Kombinasi Band 123

\section{Pemotongan Citra (Cropping)}

Pemotongan citra dilakukan untuk membuat pengolahan citra menjadi lebih fokus pada wilayah yang akan diteliti. Ada 2 tahapan yang dilakukan, yaitu pemotongan citra berdasarkan hasil digitasi dari peta RBI untuk menentukan batasan area penelitian, setelah itu proses pemotongan citra yang dilakukan untuk mendapatkan wilayah daratan dan lautan, dimana vektor yang digunakan merupakan hasil digitasi dari proses masking pada setiap citra masing - masing tahun, sehingga didapatkan 6 batas area yang berbeda yaitu 3 vektor daratan dan 3 vektor lautan. Proses masking terbagi menjadi dua proses, yaitu masking daratan dan lautan. Hal tersebut dibedakan, karena dalam proses klasifikasi tutupan lahan menggunakan area daratan sedangkan klasifikasi kekeruhan air laut menggunakan area lautan. Berikut ini contoh hasil pemotongan citra: 


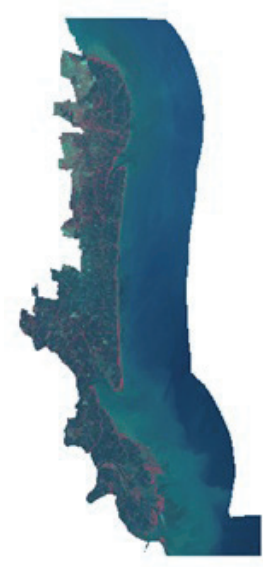

(a)

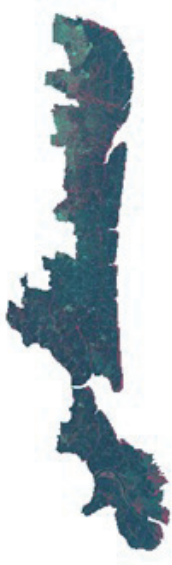

(b)

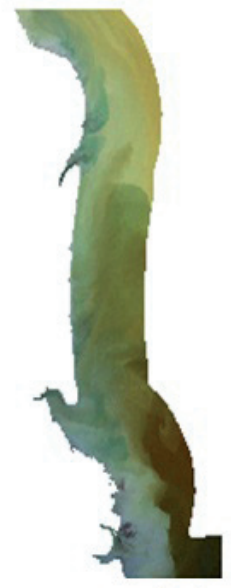

(c)
Gambar 7. Hasil Pemotongan Citra SPOT-4 Tahun 2009 Area Penelitian(a), SPOT-4 Tahun 2009 Area Daratan(b), ALOS/AVNIR Tahun 2008 Area Lautan(c)

\section{Klasifikasi}

Citra ALOS AVNIR-2 dan SPOT-4 yang sudah terkoreksi dan dipotong sesuai area penelitian tersebut selanjutnya dilakukan proses klasifikasi. Proses klasifikasi dilakukan dengan menggunakaan metode terselia berdasarkan kemiripan maksimum (maximum likehood) karena hasil klasifikasi pada metode ini lebih peka terhadap pola tanggapan spektral dan lebih teliti dibandingkan metode klasifikasi tak terselia.

Pada penelitian ini, citra yang digunakan dibagi menjadi 6 kelas, yaitu: (1) Pemukiman, (2) Empang, (3) Tegalan/ladang, (4) Rumput/ tanah kosong, (5) Badan air, (6) Hutan rawa, dimana pembagian kelas ini mengacu pada peta Rupa Bumi Indonesia (RBI).

Berikut ini hasil luasan kelas tutupan lahan masing - masing citra, sebagai berikut :

Tabel 3. Luasan Kelas Tutupan Lahan Tahun 2006Berikut ini peta hasil klasifikasi tutupan lahan tahun 2006 - 2009:

Tabel 3. Luasan Kelas Tutupan Lahan Tahun 2006

\begin{tabular}{|c|c|c|}
\hline Tahun & Kelas & Luas (Ha) \\
\hline \multirow{4}{*}{2006} & Tegalan/Ladang & 389,36 \\
\cline { 2 - 3 } & Rumput/Tanah Kosong & 711,51 \\
\cline { 2 - 3 } & Hutan Rawa & 1436,57 \\
\cline { 2 - 3 } & Pemukiman & 806,46 \\
\cline { 2 - 3 } & Empang & 14233,36 \\
\cline { 2 - 3 } & Badan Air & 230,17 \\
\hline \multicolumn{2}{|c}{ Total } & 17807,43 \\
\hline
\end{tabular}

Tabel 4. Luasan Kelas Tutupan Lahan Tahun 2008

\begin{tabular}{|c|c|c|}
\hline Tahun & Kelas & Luas (Ha) \\
\hline \multirow{3}{*}{2008} & Tegalan/Ladang & 315,99 \\
\cline { 2 - 3 } & Rumput/Tanah Kosong & 483,94 \\
\cline { 2 - 3 } & Hutan Rawa & 1627,93 \\
\cline { 2 - 3 } & Pemukiman & 981,5 \\
\cline { 2 - 3 } & Empang & 14231,08 \\
\cline { 2 - 3 } & Badan Air & 218 \\
\hline \multicolumn{2}{|c|}{ Total } & 17858,44 \\
\hline
\end{tabular}

Tabel 5. Luasan Kelas Tutupan Lahan Tahun 2009

\begin{tabular}{|c|c|c|}
\hline Tahun & Kelas & Luas (Ha) \\
\hline \multirow{4}{*}{2009} & Tegalan/Ladang & 397,88 \\
\cline { 2 - 3 } & Rumput/Tanah Kosong & 426,88 \\
\cline { 2 - 3 } & Hutan Rawa & 1594,44 \\
\cline { 2 - 3 } & Pemukiman & 991,16 \\
\cline { 2 - 3 } & Empang & 14185,32 \\
\cline { 2 - 3 } & Badan Air & 243,84 \\
\hline \multicolumn{2}{|c}{ Total } & 17839,52 \\
\hline
\end{tabular}

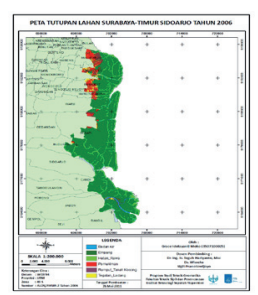

(a)

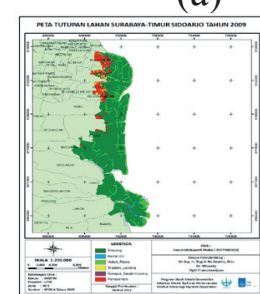

(c)

Gambar 8. Hasil Klasifikasi Tutupan Lahan Tahun 2006 (a), 2008 (b), 2009 (c)

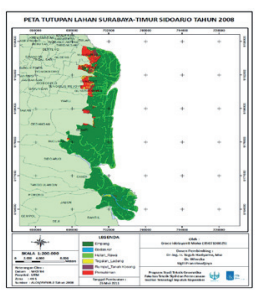

(b) 


\section{Penerapan Algoritma TSS}

Algoritma TSS digunakan untuk mendapatkan kandungan nilai TSS (mg/l) pada citra dengan cara memasukkan persamaan algoritma ke dalam tool formula editor pada software ER Mapper 7.0. Persamaan algoritma yang digunakan pada citra ALOS/AVNIR-2 dan SPOT-4 berbeda. Pada citra ALOS/AVNIR menggunakan nilai digital number (DN) sedangkan SPOT-4 menggunakan nilai reflektan

a. ALOS/AVNIR-2 (Hendrawan dan Asai 2008)

$\operatorname{TSS}(m g / L)=-1.315 b 1+2.371 b 2-0.791 b 3+9.649$

$b 1=$ Digital Numberband 1

b2 $=$ Digital Numberband 2

b3 = Digital Numberband 3

b. SPOT-4 (Budhiman, 2004)

$\operatorname{TSS}(m g / L)=7,9038 * \exp (23,942 *$ red band $)$ red band $=$ reflek $\tan$ band 2

Hasil klasifikasi dari masing - masing citra kemudian dikelaskan dengan nilai interval 50 mg/l. Namun hasil klasifikasi pada setiap tahunnya menghasilkan range nilai TSS yang berbeda - beda sehingga jumlah kelas setiap tahunnya berbeda.

Adapun sebaran kekeruhan secara lebih detil dapat dilihat pada tabel berikut :

Berikut ini peta sebaran kekeruhan air laut tahun 2006, 2008, dan 2009.

Tabel 6. Luasan Kelas Kekeruhan Tahun 2006

\begin{tabular}{|c|c|c|}
\hline Kelas & Keterangan (mg/) & Luasan (Ha) \\
\hline 1 & $0-50$ & 1836,87 \\
\hline 2 & $51-100$ & 2706,24 \\
\hline 3 & $101-150$ & 4463,95 \\
\hline 4 & $151-200$ & 6755,92 \\
\hline 5 & $201-250$ & 8913,54 \\
\hline 6 & $251-300$ & 4788,16 \\
\hline
\end{tabular}

Tabel 7. Luasan kelas kekeruhan tahun 2008

\begin{tabular}{|c|c|c|}
\hline Kelas & Keterangan (mg/) & Luasan (Ha) \\
\hline 1 & $0-50$ & 4285,63 \\
\hline 2 & $51-100$ & 6407,14 \\
\hline 3 & $101-150$ & 10352,97 \\
\hline 4 & $151-200$ & 8235,47 \\
\hline
\end{tabular}

Tabel 8. Luasan Kelas Kekeruhan Tahun 2009

\begin{tabular}{|c|c|c|}
\hline Kelas & Keterangan (mg/) & Luasan (Ha) \\
\hline 1 & $0-50$ & 4728,32 \\
\hline 2 & $51-100$ & 3622 \\
\hline 3 & $101-150$ & 5582,48 \\
\hline 4 & $151-200$ & 5788,96 \\
\hline 5 & $201-250$ & 4894,04 \\
\hline 6 & $251-300$ & 3722,4 \\
\hline 7 & $301-350$ & 1015,12 \\
\hline
\end{tabular}

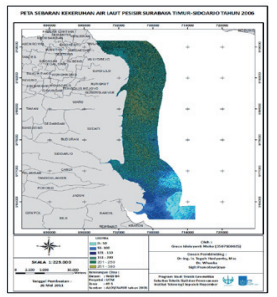

(a)

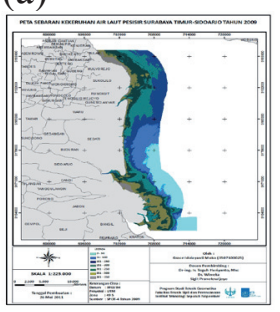

(c)

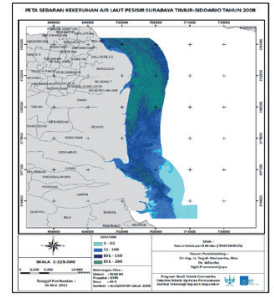

(b)
Gambar 9. Hasil Peta Sebaran Kekeruhan Air Laut Tahun 2006 (A), 2008 (B), 2009 (C)

\section{Digitasi Garis Pantai}

Penentuan garis pantai secara cepat dan praktis dapat dilakukan dengan cara interpretasi visual pada citra sekaligus melakukan on screen digitizing pada citra tersebut. Digitasi dilakukan setelah melakukan proses masking, yaitu pemisahan daratan dengan lautan. Digitasi dilakukan dengan menggunakan software ER Mapper 7.0. Berikut ini hasil digitasi garis pantai tahun 2006, 2008, dan 2009. 


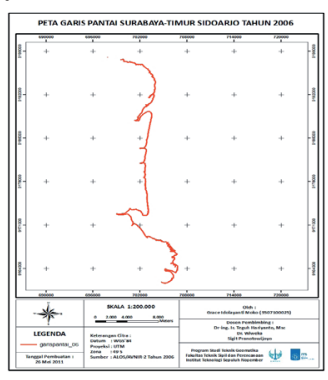

(a)

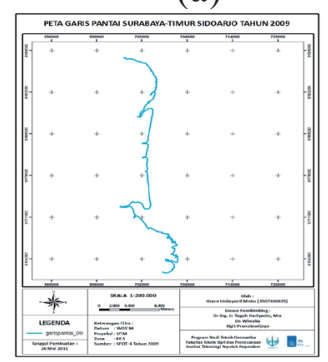

(c)

Gambar 10. Garis Pantai Tahun 2006 (a), 2008 (b), dan 2009 (c)

\section{ANALISIS}

\section{Uji Ketelitian Klasifikasi}

Adapun citra yang diujikan ke lapangan adalah citra tahun terakhir, yaitu citra SPOT-4 dengan akuisisi 21 Juli 2009.

Uji ketelitian dilakukan dengan menggunakan perhitungan confusion matrix. Caranya yaitu dengan membandingkan sampel titik - titik koordinat pada tiap - tiap jenis kelas tutupan lahan hasil klasifikasi, dengan kondisi koordinat sebenarnya dilapangan untuk mengetahui kebenaran hasil dari klasifikasi. Jika hasil perhitungan confusion matrix $\geq 80 \%$ maka klasifikasi citra dianggap benar (Short, 1982 dalam Adry, 2009).

Dari hasil perhitungan confusion matrix yang sudah dilakukan, didapatkan hasil ketelitian seluruh hasil klasifikasi $(\mathrm{KH})$ untuk citra SPOT-4 bulan Juli 2009 sebesar 86\%. Dengan hasil perhitungan ketelitian klasifikasi yang didapatkan sebesar 86\%. maka klasifikasi dianggap benar karena nilainya lebih besar dari $80 \%$.

Tabel 9. Matriks Uji Ketelitian Klasifikasi Tutupan Lahan

\begin{tabular}{|c|l|c|c|c|c|c|c|c|c|c|}
\hline $\begin{array}{l}\mathrm{N} \\
\mathbf{0}\end{array}$ & \multicolumn{1}{|c|}{ Kelas } & $\mathbf{1}$ & $\mathbf{2}$ & $\mathbf{3}$ & $\mathbf{4}$ & $\mathbf{5}$ & $\mathbf{6}$ & $\mathrm{T}$ & $\mathbf{O}$ & $\mathrm{MA}$ \\
\hline $\mathbf{1}$ & Tegalan/Ladang & 3 & 0 & 0 & 0 & 0 & 0 & 3 & 0 & 100 \\
\hline $\mathbf{2}$ & $\begin{array}{l}\text { Rumput/Tanah } \\
\text { Kosong }\end{array}$ & 0 & 4 & 0 & 0 & 0 & 0 & 4 & 0 & 100 \\
\hline 3 & Pemukiman & 0 & 0 & 6 & 0 & 0 & 0 & 6 & 0 & 100 \\
\hline 4 & Badan Air & 0 & 0 & 0 & 2 & 0 & 0 & 2 & 0 & 100 \\
\hline 5 & Hutan Rawa & 0 & 0 & 0 & 0 & 1 & 4 & 5 & 4 & 20 \\
\hline 6 & Empang & 0 & 0 & 0 & 0 & 0 & 10 & 10 & 0 & 100 \\
\hline$\quad$ Total & 3 & 4 & 6 & 2 & 1 & 14 & 30 & 5 & 86,6 \\
\hline$\quad$ Komisi & 0 & 0 & 0 & 0 & 0 & 4 & 4 & 13 & \\
\hline
\end{tabular}

$\mathrm{T}=$ total, $\mathbf{O}=$ omisi

\section{ANALISIS PERUBAHAN LUASAN TU- TUPAN LAHAN}

Berikut ini merupakan perubahan penutup lahan yang terjadi pada tahun 2006 - 2009.

Tabel 10. Perubahan Luas Penutup Lahan Tahun 2006-2008

\begin{tabular}{|c|c|c|c|c|}
\hline \multirow{2}{*}{ Kelas } & \multicolumn{2}{|c|}{ Luasan (Ha) } & Perubahan Luasan \\
\cline { 2 - 5 } & $\mathbf{2 0 0 6}$ & $\mathbf{2 0 0 8}$ & + & - \\
\hline Tegalan/Ladang & 389,36 & 315,99 & 0 & 73,37 \\
\hline Rumput/Tanah Kosong & 711,51 & 483,94 & 0 & 227,57 \\
\hline Hutan Rawa & 1436,57 & 1627,93 & 191,36 & 0 \\
\hline Pemukiman & 806,46 & 981,5 & 175,04 & 0 \\
\hline Empang & 14233,36 & 14231,08 & 0 & 2,28 \\
\hline Badan Air & 230,17 & 218 & 0 & 12,17 \\
\hline
\end{tabular}

Tabel 11. Perubahan Luas Penutup Lahan Tahun 2008-2009

\begin{tabular}{|c|c|c|c|c|}
\hline \multirow{2}{*}{ Kelas } & \multicolumn{2}{|c|}{ Luasan (Ha) } & \multicolumn{2}{c|}{$\begin{array}{c}\text { Perubahan } \\
\text { Luasan }\end{array}$} \\
\cline { 2 - 5 } & $\mathbf{2 0 0 6}$ & $\mathbf{2 0 0 8}$ & + & - \\
\hline Tegalan/Ladang & 315,99 & 397,88 & 81,89 & 0 \\
\hline Rumput/Tanah Kosong & 483,94 & 426,88 & 0 & 57,06 \\
\hline Hutan Rawa & 1627,93 & 1594,44 & 0 & 33,49 \\
\hline Pemukiman & 981,5 & 991,16 & 9,66 & 0 \\
\hline Empang & 14231,08 & 14185,32 & 0 & 45,76 \\
\hline Badan Air & 218 & 243,84 & 25,84 & 0 \\
\hline
\end{tabular}

Berdasarkan tabel diatas, dapat dilihat bahwa terdapat beberapa perubahan luasan yang terjadi, ada yang mengalami penambahan dan ada juga yang berkurang. Terlihat bahwa dari tiga tahun terakhir kelas Rumput/tanah kosong 
dan Empang, selalu mengalami penurunan luasan. Hal tersebut dapat disebabkan karena adanya perubahan fungsi lahan, menjadi Pemukiman, Hutan rawa, maupun Tegalan/ ladang, karena pada kelas-kelas tersebut mengalami penambahan luasan. Hal ini diperkuat dengan penelitian yang dilakukan Yuliati (2010) yang menjelaskan bahwa pada tahun 2006-2009 terjadi penambahan luas hutan mangrove, penambahan ini terjadi karena adanya proses sedimentasi yang berasal dari lumpur Sidoarjo yang terjadi pada kawasan pesisir Surabaya-Sidoarjo serta adanya rehabilitasi hutan mangrove.

\section{ANALISIS PERUBAHAN GARIS PANTAI}

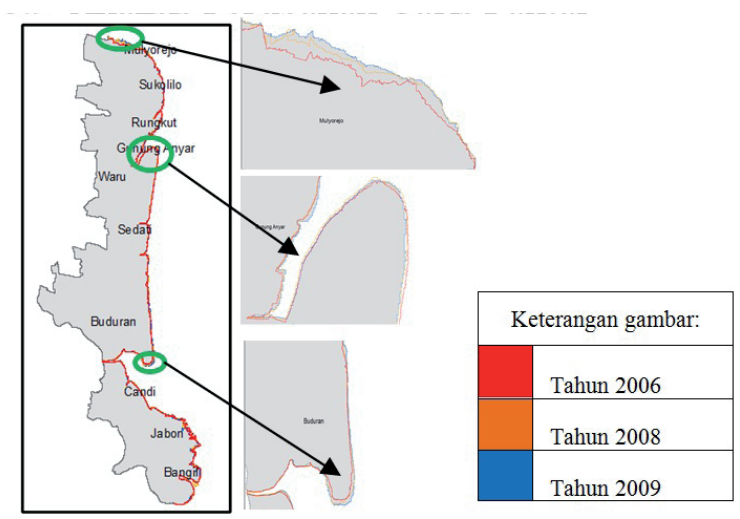

Gambar 11. Lokasi Perubahan Daratan

Garis pantai diperoleh dari hasil digitasi, dimana digitasi dilakukan per piksel pada citra. Sehingga dari hasil digitasi tersebut didapatkan panjang garis pantai.Perhitungan panjang garis pantai hasil digitasi dilakukan menggunakan software ER Mapper 7.0. Perubahan panjang garis pantai dipengaruhi oleh bentuk garis pantai yang tidak lurus. Secara lebih rinci, perubahan panjang garis pantai dan perubahan daratan tahun 2006 ke 2009 dapat dilihat pada tabel di bawah ini.
Tabel 12. Perubahan Garis Pantai

\begin{tabular}{|c|c|c|}
\multicolumn{3}{|c}{ Tahun 2006 - 2009 } \\
\hline Tahun & Panjang Garis Pantai (km) & Perubahan (km) \\
\hline 2006 & 106,87 & 0 \\
\hline 2008 & 98,82 & $-8,05$ \\
\hline 2009 & 92,38 & $-6,44$ \\
\hline
\end{tabular}

Tabel 13. Perubahan Daratan Tahun 2006 - 2009

\begin{tabular}{|c|c|c|}
\hline Tahun & Luas (ha) & Perubahan Luas Daratan (ha) \\
\hline 2006 & 17807,43 & 0 \\
\hline 2008 & 17858,44 & $+51,01$ \\
\hline 2009 & 17839,52 & $-18,92$ \\
\hline
\end{tabular}

Berdasarkan tabel diatas, dapat dilihat terjadi perubahan garis pantai yang diikuti dengan adanya perubahan daratan. Perubahan tersebut dapat disebabkan oleh beberapa hal, diantaranya adalah:

a.Sedimen yang dibawa oleh sungai - sungai yang bermuara di pantai Surabaya-Sidoarjo, misalnya Sungai Brantas dan Sungai Porong.

b.Reklamasi yang dilakukan oleh penduduk di daerah pantai atau developer.

c.Sedimen yang berasal dari pembuangan lumpur Lapindo melalui Kali Porong.

Menurut Widjiharti (2008) di sepanjang Pantai Timur Sidoarjo, sejak tahun 1945 s.d. 1997 telah terjadi proses angkutan sedimen secara terus menerus yang menimbulkan penambahan daratan kearah laut sebesar $\pm 144,615 \mathrm{~m} 2 /$ th dan mengakibatkan lokasi muara - muara sungai bergeser dari lokasi muara semula. Untuk prediksi sampai tahun 2010 diperoleh hasil pengamatan bahwa di lokasi penelitian secara komulatif masih akan terjadi penambahan daratan pada setiap tahun namun dengan angka luas penambahan yang makin mengecil. Selain itu, menurut Mayasari (2010), terjadi perubahan daratan yang cukup signifikan antara 2 periode, 147,978 ha antara tahun 2003 sampai 2006 dan 213,888ha antara tahun 2006 sampai 2009. Dari hasil ini diindikasikan bahwa terjadi peningkatan laju sedimentasi. 


\section{Analisis Hasil Algoritma}

Nilai TSS hasil pengolahan citra bervariatif. Pada tahun 2006 berkisar antara $0-300 \mathrm{mg} / \mathrm{l}$, tahun 2008 antara 0 - $200 \mathrm{mg} / \mathrm{l}$, sedangkan tahun 2009 nilai TSS meningkat yaitu berkisar $0-350 \mathrm{mg} / \mathrm{l}$.

Angka kekeruhan yang paling tinggi terjadi pada tahun 2009, nilai kekeruhan yang didapat mencapai $350 \mathrm{mg} / \mathrm{l}$. Kisaran nilai kekeruhan pada wilayah perairan Surabaya - Sidoarjo berkisar antara 0 - $200 \mathrm{mg} / \mathrm{l}$. Sedangkan penelitian yang dilakukan Mayasari (2010), menjelaskan bahwa dari tahun 2003 ke 2009, persebaran kelas sedimentasi relatif tetap pada masing-masing kelas sedimentasi. Sebaran sedimentasi di sepanjang pantai Surabaya Sidoarjo didominasi oleh nilai TSS 25-125 $\mathrm{mg} / \mathrm{l}$. Namun terdapat perbedaan hasil antar keduanya. Hal ini dapat disebabkan karena adanya perbedaan waktu pada uji lapangan/ ground truth. Penelitian yang dilakukan oleh Mayasari (2010), dilakukan pada Maret 2010, sedangkan dalam penelitian ini uji lapangan dilakukan pada bulan Mei 2011. Selain itu, area peneltiannya berbeda. Untuk penelitian yang dilakukan Mayasari (2010) area penelitiannya berada pada pesisir Surabaya - Sidoarjo secara keseluruhan, sedangkan pada penelitian ini dilakukan pada pesisir Surabaya Timur - Sidoarjo.

Tabel 14. Perbandingan Luasan Kelas Kekeruhan

\begin{tabular}{|c|c|c|c|c|}
\hline \multirow{2}{*}{ Kelas } & \multirow{2}{*}{ Keterangan (mg/l) } & \multicolumn{3}{|c|}{ Luasan (Ha) } \\
\cline { 3 - 5 } & & $\mathbf{2 0 0 6}$ & $\mathbf{2 0 0 8}$ & $\mathbf{2 0 0 9}$ \\
\hline 1 & $0-50$ & 1836,87 & 4285,63 & 4728,32 \\
\hline 2 & $51-100$ & 2706,24 & 6407,14 & 3622 \\
\hline 3 & $101-150$ & 4463,95 & 10353 & 5582,48 \\
\hline 4 & $151-200$ & 6755,92 & 8235,47 & 5788,96 \\
\hline 5 & $201-250$ & 8913,54 & & 4894,04 \\
\hline 6 & $251-300$ & 4788,16 & & 3722,4 \\
\hline 7 & $301-350$ & & & 1015,12 \\
\hline
\end{tabular}

\section{Analisis Hasil Ground Truth}

Ground Truth dilakukan pada tanggal 4 Mei 2011 - 7 Mei 2011 di perairan Surabaya Timur-Sidoarjo. Berikut ini adalah tabel di perairan Surabaya Timur dan perbandingan hasil pengolahan citra SPOT-4 dengan hasil uji lapangan yang dilakukan dengan menggunakan alat Water Quality Checker.

Tabel 15. Perbandingan Hasil Uji Lapangan Dengan Pengolahan Citra SPOT-4

\begin{tabular}{|c|c|c|c|c|c|}
\hline \multirow{2}{*}{ No } & \multicolumn{2}{|c|}{ Koordinat } & \multirow{2}{*}{$\begin{array}{l}\text { Hasil } \\
\text { Citra } \\
(\mathrm{mg} / \mathrm{d})\end{array}$} & \multirow{2}{*}{$\begin{array}{c}\text { Hasil } \\
\text { Lapangan } \\
(\mathrm{mg} / \mathrm{l})\end{array}$} & \multirow{2}{*}{$\Delta(\mathrm{mg} / \mathrm{l})$} \\
\hline & $\mathrm{X}(\mathrm{m})$ & $\mathrm{Y}(\mathrm{m})$ & & & \\
\hline 1 & 698647 & 9199429 & 260,5 & 103,7 & 156,81 \\
\hline 2 & 699003 & 9199084 & 245,7 & 97,7 & 147,95 \\
\hline 3 & 699259 & 9199085 & 212,1 & 90,5 & 121,59 \\
\hline 4 & 699597 & 9199090 & 183,1 & 121,3 & 61,83 \\
\hline 5 & 699947 & 9199085 & 200 & 124,4 & 75,59 \\
\hline 6 & 700404 & 9199083 & 158,1 & 111,5 & 46,61 \\
\hline 7 & 700744 & 9198987 & 172,7 & 131,7 & 40,97 \\
\hline 8 & 701263 & 9198896 & 162,8 & 95,6 & 67,23 \\
\hline 9 & 701684 & 9199028 & 140,6 & 77 & 63,58 \\
\hline 10 & 701944 & 9199052 & 128,7 & 35,6 & 93,12 \\
\hline 11 & 702893 & 9198985 & 121,4 & 29,2 & 92,18 \\
\hline 12 & 703439 & 9199134 & 122,68 & 32,9 & 89,78 \\
\hline 13 & 703845 & 9199195 & 114,5 & 17,7 & 96,75 \\
\hline 14 & 704177 & 9199155 & 107,9 & 12,1 & 95,82 \\
\hline 15 & 704599 & 9199130 & 107,9 & 11,8 & 96,12 \\
\hline 16 & 705093 & 9199096 & 98,92 & 14,4 & 84,52 \\
\hline 17 & 705418 & 9199062 & 93,18 & 14,8 & 78,38 \\
\hline 18 & 705816 & 9199025 & 93,18 & 15,9 & 77,28 \\
\hline 19 & 706310 & 9199042 & 98,82 & 17,2 & 81,62 \\
\hline 20 & 706548 & 9199060 & 98,82 & 26 & 72,82 \\
\hline 21 & 707143 & 9199082 & 90,48 & 13,2 & 77,28 \\
\hline 22 & 707524 & 9199095 & 82,85 & 13,8 & 69,05 \\
\hline 23 & 707800 & 9198643 & 87,87 & 16,4 & 71,47 \\
\hline 24 & 707955 & 9197933 & 85,32 & 9,9 & 75,42 \\
\hline 25 & 708011 & 9196882 & 90,48 & 22,6 & 67,88 \\
\hline 26 & 705445 & 9195013 & 136,5 & 72,2 & 64,32 \\
\hline 27 & 704093 & 9191940 & 162,8 & 58,7 & 104,12 \\
\hline 28 & 704380 & 9193448 & 188,6 & 45,2 & 143,38 \\
\hline 29 & 704285 & 9194252 & 172,7 & 51,3 & 121,37 \\
\hline 30 & 704472 & 9194920 & 158,1 & 115,2 & 42,91 \\
\hline 31 & 703773 & 9195066 & 172,7 & 82,2 & 90,47 \\
\hline 32 & 703673 & 9195581 & 162,8 & 84,5 & 78,32 \\
\hline 33 & 703477 & 9196105 & 200 & 94,8 & 105,19 \\
\hline 34 & 703075 & 9196475 & 253 & 63,5 & 189,46 \\
\hline 35 & 702792 & 9196982 & 212,1 & 80,2 & 131,89 \\
\hline 36 & 702246 & 9197297 & 276,3 & 97,4 & 178,87 \\
\hline 37 & 701455 & 9197852 & 310,7 & 67,8 & 242,91 \\
\hline 38 & 700992 & 9198435 & 224,9 & 57,6 & 167,32 \\
\hline 39 & 700306 & 9198883 & 188,6 & 77,3 & 111,28 \\
\hline 40 & 699631 & 9198516 & 238,5 & 66 & 172,53 \\
\hline 41 & 706807 & 9163216 & 104,8 & 56,2 & 48,6 \\
\hline 42 & 707451 & 9162789 & 95,96 & 42,7 & 53,26 \\
\hline 43 & 708561 & 9162450 & 158,1 & 13,6 & 144,51 \\
\hline 44 & 709687 & 9162165 & 144,8 & 4,4 & 140,37 \\
\hline 45 & 710562 & 9161670 & 158,1 & 4.1 & 154.01 \\
\hline 46 & 711002 & 9161113 & 125 & 12,7 & 112,3 \\
\hline 47 & 710255 & 9160906 & 149,1 & 2,6 & 146,49 \\
\hline$\frac{48}{49}$ & $\frac{709572}{109368}$ & $\frac{9160582}{9160733}$ & $\frac{153.5}{144.8}$ & $\frac{5.6}{14.8}$ & $\frac{147.93}{129.97}$ \\
\hline$\frac{49}{50}$ & $\begin{array}{r}0.9368 \\
708635 \\
\end{array}$ & $\begin{array}{l}91600133 \\
9160132\end{array}$ & $\begin{array}{l}\frac{14.8}{158.1} \\
\end{array}$ & $\frac{14.8}{15.3}$ & $\frac{129,91}{142.81}$ \\
\hline$\frac{51}{52}$ & 708411 & $\frac{91601717}{9160011}$ & $\frac{16,7}{194,2}$ & $\frac{18,6}{22.3}$ & $\frac{149,07}{171.9}$ \\
\hline 53 & 707548 & 9160101 & 208.2 & 24.2 & $\frac{183.99}{183.99}$ \\
\hline$\frac{54}{55}$ & 707444 & $\frac{9160610}{9160942}$ & $\frac{172.7}{140.6}$ & $\frac{40,9}{76.6}$ & $\frac{131.77}{63.98}$ \\
\hline 56 & $\frac{07393}{706915}$ & $\frac{9161464}{9165458}$ & $\frac{172.7}{121.4}$ & $\frac{39.2}{14.5}$ & $\frac{133.47}{136.88}$ \\
\hline 58 & $\frac{10915}{0.06439}$ & 9161688 & $\frac{121.4}{162.8}$ & 34.9 & $\begin{array}{l}40,80 \\
127,92\end{array}$ \\
\hline$\frac{59}{60}$ & $\frac{705959}{706375}$ & $\frac{9161816}{9162412}$ & $\frac{15.5}{32.6}$ & $\begin{array}{l}\frac{42,1}{59,3} \\
\end{array}$ & $\frac{111.43}{73.26}$ \\
\hline 61 & 706877 & 9161750 & 149.1 & 41.9 & 107,19 \\
\hline 63 & 707016 & $\frac{9101050}{9161543}$ & 183.1 & $\frac{716}{40.5}$ & $\frac{\frac{120.51}{136.63}}{\frac{1124}{12}}$ \\
\hline
\end{tabular}

Nilai TSS hasil yang diperoleh dari 
pengambilan sampel lapangan mempunyai nilai yang berbeda dengan kelas TSS dari hasil pengolahan citra. Adapun perbedaan tersebut antara lain dapat disebabkan beberapa hal berikut:

Perbedaan musim pengambilan data lapangan dan tanggal akuisisi citra, dimana citra memiliki akuisisi pada musim kemarau, dan pengambilan data data lapangan dilakukan pada bulan Mei, dimana sedang terjadi musim pancaroba, peralihan musim kemarau ke musim penghujan.

Kondisi pada saat pengambilan data lapangan, pengambilan data dilakukan setelah turun hujan sehingga akan berbeda dengan pengambilan data yang dilakukan pada saat tidak turun hujan.

Uji korelasi dilakukan dengan membandingkan hasil TSS citra dengan hasil ground truth. Hal ini dilakukan untuk mengetahui sejauh mana korelasi atau kedekatan hasil TSS pengolahan citra dengan hasil lapangan.

Untuk mengetahui kekuatan hubungan antara dua peubah yaitu hasil pengolahan citra dan data pengukuran lapangan, perlu dilakukan perhitungan korelasi.

Berikut ini grafik yang menunjukan korelasi antara data lapangan dan hasil pengolahan citra. Uji korelasi ini dilakukan dengan membandingkan hasil TSS citra dengan hasil ground truth. Hal ini dilakukan untuk mengetahui sejauh mana korelasi atau kedekatan hasil TSS pengolahan citra dengan hasil lapangan. Pada uji korelasi ini didapatkan nilai $\mathrm{r}^{2}=0,299$, seperti pada gambar 4.19.
Dengan persamaan sebagai berikut :

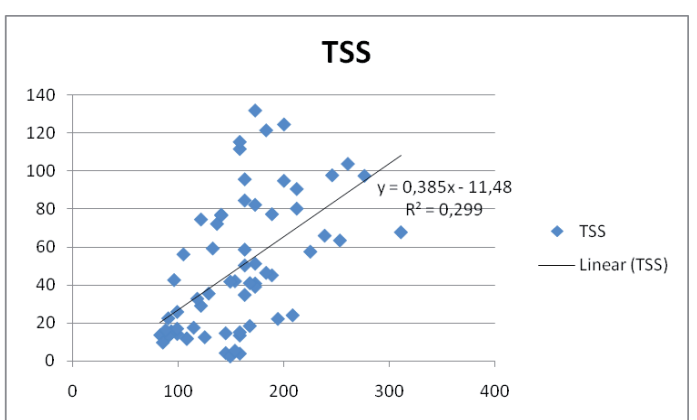

Gambar 12. Grafik hasil TSS citra dan data lapangan

Pada uji korelasi ini didapatkan nilai $\mathbf{r}^{2}=0,299$. Dengan persamaan sebagai berikut :

$\mathrm{y}=0,385 \mathrm{x}-11,48$

Nilai $r^{2}=0,299$ bermakna bahwa 0,299 atau $\mathbf{2 9 , 9 \%}$ diantara keragaman total nilai lapangan (y) tidak dapat dijelaskan oleh hubungan liniernya dengan nilai citra $(x)$. Sehingga dapat disimpulkan antara hasil citra dan data lapangan mempunyai hubungan linier yang sangat lemah. Berikut ini distribusi nilai TSS hasil pengukuran lapangan dan hasil pengolahan citra. Hubungan linier sempurna bila $r=+1$ atau -1 . Bila $r$ mendekati +1 atau -1 , hubungan antara dua peubah itu kuat dan dapat dikatakan terdapat korelasi yang tinggi antara keduanya. Akan tetapi, bila $r$ mendekati nol, hubungan linier antara $\mathrm{X}$ dan $\mathrm{Y}$ sangat lemah atau mungkin tidak ada sama sekali. (Walpole, 1995)

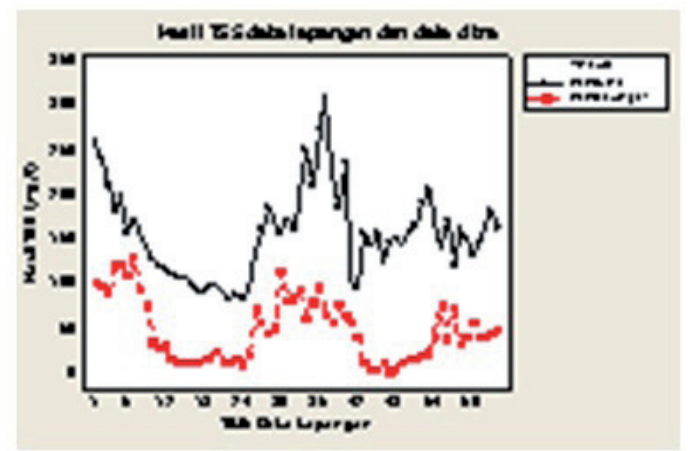

Gambar 13. Pola Distribusi Nilai TSS Lapangan Dan Hasil Pengolahan Citra SPOT-4 
Grafik di atas menunjukan pola distibusi nilai TSS hasil pengolahan citra pada SPOT-4 tahun 2009 dengan hasil pengukuran lapangan. Dari grafik tersebut dapat disimpulkan bahwa antara hasil pengolahan citra dan data lapangan mempunyai kecenderungan pola yang sama. Namun, masih terdapat perbedaan pola pada titik - titik tertentu.

\section{Analisis Berdasarkan Musim}

Sesuai data curah hujan dan pencatatan angin yang diperoleh dari BMKG statiun Tanjung Perak, Surabaya, diketahui bahwa citra satelit yang digunakan berada pada satu musim yang sama dimana musim pada saat musim kemarau pengaruh angin timur lebih dominan. Hal ini terjadi pada bulan Mei-Oktober.

Sedangkan pada saat pengambilan data lapangan, yaitu pada bulan Mei tahun 2011, tercatat bahwa terjadi peralihan musim antara musim penghujan ke musim kemarau yaitu musim pancaroba sehingga menyebabkan terjadi perbedaan hasil lapangan dengan hasil pengolahan citra.

\section{Analisis Berdasarkan Pasang Surut}

Pasang surut mempengaruhi tingkat kekeruhan air laut. Jika pada kondisi pasang, maka distribusi air akan terjadi dari laut menuju sungai sehingga distribusi partikel - partikel tersuspensi juga mengalir dari laut menuju sungai, sedangkan jika saat kondisi surut maka akan terjadi aliran air dari sungai ke laut, sehingga material dan partikel tersuspensi juga akan mengalir dari sungai menuju laut. Berikut ini tabel pasang surut berdasarkan data pasang surut yang dikeluarkan oleh Dinas Hidrografi dan Oceanografi TNI AL (Dishidros).
Tabel 16. Kondisi Pasang Surut Citra Yang Digunakan

\begin{tabular}{|c|c|c|c|}
\hline Citra & Akuisisi & $\begin{array}{c}\text { Tinggi } \\
\text { Pasut } \\
(\mathbf{m})\end{array}$ & Keterangan \\
\hline Alos/AVNIR-2 & $\begin{array}{c}\text { 6 Oktober 2006 } \\
\text { 10:30 WIB }\end{array}$ & 2,3 & Menuju Surut \\
\hline Alos/AVNIR-2 & $\begin{array}{c}\text { 11 Juli 2008 10:30 } \\
\text { WIB }\end{array}$ & 1,6 & Menuju Surut \\
\hline SPOT-4 297/364 & $\begin{array}{c}\text { 21 Juli 2009 } \\
\text { 02:37:08 WIB }\end{array}$ & 1,6 & Menuju Surut \\
\hline SPOT-4 297/365 & $\begin{array}{c}\text { 22 Juli 2009 } \\
\text { 02:37:16 WIB }\end{array}$ & 1,6 & Menuju Surut \\
\hline
\end{tabular}

Sedangkan pada saat pengambilan data lapangan dilakukan pada bulan Mei sekitar pukul 09.00 - 13.00, dimana pada saat itu, kondisi di wilayah perairan Surabaya Sidoarjo dalam kondisi menuju pasang.

Tabel 17. Kondisi Pasut Saat Pengukuran Sampel Air Laut

\begin{tabular}{|c|c|c|} 
Tanggal & Waktu & Tinggi Pasut (m) \\
\hline \multirow{4}{*}{04 Mei 2011 } & $9: 00$ & 2,4 \\
\cline { 2 - 3 } & $10: 00$ & 2,6 \\
\cline { 2 - 3 } & $11: 00$ & 2,7 \\
\cline { 2 - 3 } & $12: 00$ & 2,5 \\
\cline { 2 - 3 } & $13: 00$ & 2,2 \\
\hline \multirow{4}{*}{$07-$ Mei-11 } & $9: 00$ & 2 \\
\cline { 2 - 3 } & $10: 00$ & 2,3 \\
\cline { 2 - 3 } & $11: 00$ & 2,5 \\
\cline { 2 - 3 } & $12: 00$ & 2,6 \\
\cline { 2 - 3 } & $13: 00$ & 2,6 \\
\hline
\end{tabular}

\section{KESIMPULAN}

Hasil koreksi geometrik pada semua citra dalam penelitian ini menghasilkan nilai $R M S e \leq$ 1 piksel, sehingga koreksi geometrik dianggap benar. Dan kekuatan jaring yang diperoleh memenuhi syarat ketelitian, yaitu mendekati (0).

Berdasarkan hasil klasifikasi tutupan lahan tahun 2006 hingga 2009 didapatkan kelas Rumput/tanah kosong dan Empang setiap tahunnya berkurang, sehingga terjadi alih fungsi lahan menjadi Pemukiman, yang ditandai dengan penambahan luasan Pemukiman setiap tahunnya. 
Hasil uji ketelitian untuk klasifikasi citra SPOT4 bulan Juli 2009 menunjukkan tingkat kebenaran sebesar $86 \%$, sehingga hasil klasifikasi dianggap benar.

Berdasarkan hasil algoritma TSS, nilai kekeruhan yang dominan untuk area SurabayaSidoarjo adalah $0-200 \mathrm{mg} / \mathrm{l}$, hal itu berarti perairan Surabaya - Sidoarjo memiliki tingkat kekeruhan yang tinggi.

Diperoleh $\mathrm{r}^{2}$ sebesar 0,299 bermakna bahwa 0,29 atau 29,9\% diantara keragaman total nilai lapangan $(y)$ tidak dapat dijelaskan oleh hubungan liniernya dengan nilai citra $(x)$. Sehingga hasil citra dan data lapangan mempunyai hubungan linier yang sangat lemah.

Sejak tahun 2006 hingga 2009 terjadi perubahan garis pantai yang diikuti dengan terjadinya perubahan daratan. Pada tahun 2006 - 2008 perubahan daratan sebesar 51,01 ha sedangkan tahun 2009 - 2009 perubahannya sebesar 18,92 ha.

Peristiwa Lumpur Lapindo mempengaruhi wilayah pesisir Surabaya Timur - Sidoarjo, terlihat dengan adanya penambahan daratan dan meningkatkan-nya kekeruhan air laut pada area tersebut, yang disebabkan karena adanya pembuangan lumpur lapindo ke kali porong.

\section{DAFTAR PUSTAKA}

1. Adry, R. 2009. Evaluasi Perubahan Garis Pantai dan Tutupan Lahan Wilayah Pesisir Surabaya dan Sidoarjo. Surabay : Teknik Geomatika FTSPITS.

2. Arifin, I. 2009. Studi Perubahan Muatan Padatan Tersuspensi (TSM) di Selat Madura Akibat Pembuangan
Lumpur Lapindo. Surabaya : Teknik Geomatika FTSP ITS.

3. Budiman, S. 2004. Mapping TSM Concentrations from Multisensor Satellite Image in Turbid Tropical Coastal Waters of Mahakam Delta Indonesia. ITC The Netherlands.

4. Dahuri, R. Dkk. 1996. Pengelolaan Sumber Daya Wilayah Pesisir Dan Lautan Secara Terpadu. Jakarta: P.T. Pradnya Paramita.

5. Lillesand T.M., and Kiefer R.W., 1994. Remote Sensing and Image Interpretation. Second Edition, John Wiley \& Sons, New York.

6. Lukitasari, F. 2009. Evaluasi Perubahan Tutupan Lahan Wilayah Pesisir Surabaya Timur Menggunakan Citra SPOT-4 Mutispektral dan Peta LPI (Lingkungan Pantai Indonesia) Tahun 1983. Surabaya: Teknik Geodesi FTSP-ITS.

7. Ladys, M. 2011. Teknik Penentuan Perubahan Garis Pantai Utara Di Pesisir Jawa Tengah Dengan Teknologi Penginderaan Jauh Di LAPAN. Palembang : Program Studi Ilmu Kelautan-UNSRI.

8. Mayasari, R. 2010. Analisis Sedimentasi Pantai Surabaya-Sidoarjo Pasca Pembangunan Jembatan Suramadu Dan Peristiwa Lapindo Menggunakan Citra Satelit Spot-4 . Surabaya : Teknik Geomatika FTSP-ITS.

9. Pahlevi, A. M. 2009. Analisis Sedimentasi Di Muara Kali Porong Akibat Pembuangan Lumpur Lapindo Menggunakan Data Citra Satelit Aster. Surabaya : Teknik Geomatika FTSPITS.

10. Purwadhi, S. H. 2001. Interpretasi Citra Digital. Grasindo. Jakarta. 
11. Rais, J. 2003. Pedoman Penentuan Batas Wilayah Laut Kewenangan Daerah Menurut UU No. 22 Tahun 1999. Jakarta.

12. Sukojo, B.M. 2006. Modul Ajar Hitung Kerangka Geodesi. Surabaya : Teknik Geomatika, Institut Teknologi Sepuluh Nopember.

13. Susiati, H., Kusratmoko, E., dan Poniman, A., 2010. Pola Sebaran Sedimen Tersuspensi Melalui Pendekatan Penginderaan Jauh Di Perairan Pesisir Semenanjung Muria - Jepara. Jurnal Teknologi Pengolahan Limbah Volume 13, ISSN 1410-9565
14. Sutikno. 1999. Karakteristik Bentuk Pantai Materi Perkuliahan Geografi Pesisir Dan Kelautan. Yogyakarta : UGM

15. Thoha, A.S. 2008. Karakteristik Citra Satelit. Medan: Departemen Kehutanan Fakultas Pertanian Universitas Sumatera Utara.

16. Walpole, R. E. Pengantar Statistika. Jakarta : PT. Gramedia Pustaka Utama.

17. Yuliati, E, A. 2010. Analisis Perubahan Ekosistem Di Pantai SurabayaSidoarjo Pasca Pembangunan Jembatan Suramadu Dan Peristiwa Lapindo Dengan Citra Multitemporal. Surabaya : Teknik Geomatika FTSP ITS 